Биоактивные вещества и растения-продуценты

\title{
ДЕЙСТВИЕ АМАРАНТИНА НА СТРЕССОУСТОЙЧИВОСТЬ ТОМАТОВ (Lycopersicon esculentum Mill.), ИНВАЗИРОВАННЫХ ГАЛЛОВОЙ НЕМАТОДОЙ (Meloidogyne incognita)
}

\author{
М.С. ГИНС 1 , В.К. ГИНС 1 , П.Ф. КОНОНКОВ1, Ж.В. УДАЛОВА 2,3 , \\ С.В. ЗИНОВЬЕВА ${ }^{2}$
}

Галловые нематоды рода Meloidogyne - седентарные паразиты, поражающие корневую систему растений. Заражение ими вызывает биогенный стресс, который связан с изменениями дыхательных процессов, снижением фотосинтеза, появлением в тканях высоко реактивных радикалов кислорода с образованием токсичных промежуточных продуктов, вызывающих окислительный стресс. Высокая биологическая активность амарантина, выделенного из A. tricolor, в сочетании с антиоксидантными и антифидантными свойствами делают его перспективным фактором стрессоустойчивости растений при инвазии паразитическими нематодами. В настоящей работе мы впервые показали адаптогенные свойства амарантина в отношении растений томатов зараженных галловой нематодой. Целью работы была оценка влияния амарантина на морфофизиологические и фотосинтетические характеристики растений томата при заражении их галловой нематодой Meloidogyne incognita (Kofoid \& White, 1919) Chitwood 1949, а также изучение морфофизиологических показателей нематод из растений, обработанных амарантином. Исследования проводили в 2016-2017 годах на растениях томатов (Lycopersicon esculentum Mill.) гетерозисного гибрида $\mathrm{F}_{1}$ Карлсон со степенью устойчивости к M. incognita 30 \%. Амарантин выделяли из свежесобранных листьев амаранта ( $\boldsymbol{A}$. tricolor L.) сорта Валентина. О влиянии амарантина на жизнеспособность нематод судили по двигательной активности личинок II возраста в водных раствоpax 2,$0 ; 1,0 ; 0,75 ; 0,5$ мг/мл в опытах in vitro. Также in vitro определяли действие различных концентраций амарантина $(1,0 ; 0,5$ и 0,1 мг/мл) на прорастание семян томата, для чего их замачивали в водных растворах вещества в течение 3 ч. Проращивание осуществляли во влажной камере при $25^{\circ} \mathrm{C}$. Развитие проростков оценивали через 3,5 и 7 сут. Влияние амарантина на томаты и галловую нематоду исследовали в условиях лабораторной теплицы. Перед посадкой семена замачивали в растворах амарантина (0,5 и 1,0 мг/мл) в течение 3 ч. Рассаду в фазу 3-4 настоящих листьев опрыскивали растворами амарантина в тех же концентрациях и одновременно заражали нематодой (3 тыс. личинок/растение). Эффективность воздействия амарантина учитывали на 40-е сут после инвазии корней нематодами. Содержание хлорофиллов и каротиноидов оценивали по спектрам поглощения этанольных экстрактов листьев на 10-е и 40-е сут. Установлено, что при концентрации от 1,0 мг/мл и ниже амарантин обладает нематостатическим действием. Концентрация 2,0 мг/мл была летальной для M. incognita. Обработка семян амарантином в концентрациях 1,0 и 0,5 мг/мл стимулировала прорастание. На 5-е и 7-е сут средняя длина корешка у проростков, обработанных амарантином $(1,0$ мг/мл), превышала показатель в контроле на 10 и $18 \%($ p $\leq 0,05)$. В условиях теплицы опрыскивание вегетирующих растений 0,5 и 1,0 мг/мл водными растворами амарантина привело к снижению численности нематод на корнях. Число половозрелых самок в 1 г корня было соответственно в 2,1 и в 1,3 раза меныше по сравнению с контролем. Самки нематод из таких растений были мельче (в 1,2 раза в обоих вариантах обработки) и имели в оотеках на $15-20 \%$ меньше яиц $(p \leq 0,05)$. В зараженных растениях томата комплекс защитных механизмов, индуцированных действием экзогенного амарантина, включал стабилизацию фотосинтетических процессов, накопление антиоксидантов-каротиноидов, переключение нециклического транспорта электронов от воды на участке ФСІ на псевдоциклический, стимуляцию ростовых процессов. Таким образом, амарантин можно рассматривать в качестве нового биогенного индуктора, который в условиях защищенного грунта оказывает протективный эффект посредством активации общих неспецифических систем стрессорного ответа растения на инвазию фитопатогенов, а также обладает ростостимулирующими свойствами.

Ключевые слова: амарантин, антиоксидант, адаптогены, Amaranthus tricolor L., copт Валентина, Meloidogyne incognita, томаты, хлорофилл, каротиноиды, окислительный стресс, электронный транспорт.

Согласно современным представлениям, фитопатогены - это факторы стресса, которые вызывают комплексные защитные реакции растений, включающие как неспецифические (общие для разных типов стрессоров), так и специфические компоненты (1). Вместе с тем биогенный стресс, индуцированный фитопатогенами, имеет ряд особенностей, отли- 
чающих его от стресса, вызванного абиогенными экстремальными факторами. Это в полной мере относится и к фитопаразитическим нематодам, которые оказывают на растения многофакторное воздействие физической и химической природы (2).

Нематоды, особенно седентарные, к которым относятся галловые нематоды Meloidogyne, - опасные паразиты сельскохозяйственных растений, наносящие ущерб свыше 80 млрд евро в год (3). При инвазии растений нематодами возникают симптомы, характерные для эффектов таких экстремальных факторов, как засуха, холод, минеральное голодание. Заражение нематодами влияет на дыхательный газообмен, приводит к снижению фотосинтеза, появлению в тканях высокореактивных радикалов кислорода с образованием токсичных промежуточных продуктов, вызывающих окислительный стресс (4-6)

Среди факторов, способствующих выживанию растений при биогенном стрессе, в том числе обусловленном поражением фитопаразитическими нематодами, важную роль отводят веществам специализированного обмена. Они могут действовать на патоген как токсины, влиять на ростовые, линочные процессы и вылупление личинок; известно, что эти метаболиты обладают антифидантными и адаптогенными свойствами, изменяют состояние внутриклеточных мембран, нормализуют процессы фотосинтеза и интенсивность общего обмена у зараженных растений (7-10).

Амарант относится к числу сельскохозяйственных культур, для которых характерен богатый состав низкомолекулярных метаболитов, проявляющих защитное и иммуностимулирующее действие на живой организм $(11,12)$. Высокое содержание детеррентов, в том числе алкалоида амарантина, делает амарант малопривлекательным для многих фитопатогенов (13). Данные о поражаемости растений амаранта фитонематодами малочисленны и противоречивы. При испытании 10 видов амаранта на устойчивость к галловым нематодам в условиях Южной Африки не было выявлено образцов, устойчивых к Meloidogyne incognita paca 2 и Meloidogyne javanica (14). Однако имеются данные, указывающие на высокую степень устойчивости гибридов амаранта к галловой нематоде (15). Следует отметить положительный результат, полученный при введении растений амаранта в севооборот для борьбы с галловой нематодой $M$. javanica на пасленовых и тыквенных культурах (16). Противоречивость данных, по-видимому, связана с большим разнообразием видоспецифических свойств, включая состав и содержание вторичных метаболитов растений этого рода, насчитывающего до 90 видов.

Среди метаболитов красноокрашенных растений амаранта Amaranthus tricolor L., снижающих последствия окислительного стресса в растительном организме, выделяют фиолетово-красный бета-цианиновый пигмент амарантин. Показана способность амарантина обезвреживать супероксид-анионы $\left(\mathrm{O}_{2}{ }^{--}\right)$, свободные радикалы и хелатировать ионы двухвалентного железа (17). Экзогенно введенный амарантин увеличивает перенос электронов по нециклическому пути (реакция Хилла) в изолированных хлоропластах (18). Обнаружена способность амарантина участвовать в защитно-приспособительных реакциях в ответ на фотостресс, стимулировать рост растений и прорастание семян, а также положительный эффект при воздействии экстремальных температур и засухи (12). Амарантин проявлял защитное действие при обработке листьев огурца, пораженных сокососущим насекомым трипсом (13).

Высокая биологическая активность амарантина, выделенного из A. tricolor, в сочетании с антиоксидантными и антифидантными свойства- 
ми делают его перспективным фактором стрессоустойчивости растений при инвазии паразитическими нематодами.

В настоящей работе впервые показано адаптогенное действие амарантина при нематодной инвазии у растений томата, что выражается в активации энергетического обмена и восстановительных процессов.

Наше целью была оценка влияния амарантина на морфофизиологические и фотосинтетические характеристики растений томата при заражении галловой нематодой Meloidogyne incognita, а также изучение морфофизиологических показателей у нематод из растений, обработанных амарантином.

Методика. Исследования проводили в 2016-2017 годах на растениях томатов (Lycopersicon esculentum Mill.) гетерозисного гибрида $\mathrm{F}_{1}$ Карлсон со степенью устойчивости $30 \%$ к Meloidogyne incognita (Kofoid \& White, 1919) Chitwood 1949. Амарантин выделяли из свежесобранных листьев амаранта (A. tricolor L.) сорта Валентина селекции Всероссийского НИИ селекции и семеноводства овощных культур (авторы В.К. Гинс, П.Ф. Кононков, М.С. Гинс) (12). В опытах использовали лиофильно высушенный порошок амарантина.

О влиянии амарантина на жизнеспособность нематод судили по двигательной активности личинок II возраста в водных растворах $(2,0 ; 1,0$; 0,75; 0,5 мг/мл) в опытах in vitro. Контролем служили нематоды, помещенные в дистиллированную воду. Повторность опыта 3-кратная для каждого варианта (по 20 личинок). В эксперименте использовалась галловая нематода, культивируемая в лабораторных условиях на корнях восприимчивого сорта томата (первоисточником служил материал из совхоза «Тепличный», г. Москва). Личинок M. incognita получали из выделенных яйцевых мешков нематод, обитающих в корнях зараженных растений томата (19). Подвижность особей оценивали через 24 и 48 ч. Личинок инкубировали в термостате во влажной камере при $25^{\circ} \mathrm{C}$.

Также in vitro определяли действие различных концентраций амарантина $(1,0 ; 0,5$ и 0,1 мг/мл) на прорастание семян томата, для чего их замачивали в водных растворах вещества в течение 3 ч. В качестве контроля использовали семена, замоченные в дистиллированной воде. В каждом варианте было по 20 семян. Проращивание осуществляли во влажной камере при $25^{\circ} \mathrm{C}$. Развитие проростков оценивали через 3, 5 и 7 сут.

Влияние амарантина на томаты и галловую нематоду исследовали в условиях лабораторной теплицы. Перед посадкой семена замачивали в растворах амарантина $(0,5$ и 1,0 мг/мл) в течение 3 ч. Рассаду в фазу 3-4 настоящих листьев опрыскивали растворами амарантина в тех же концентрациях и одновременно заражали нематодой (3 тыс. личинок/растение). Контролем служили здоровые и зараженные растения, обработанные водой. Растения выращивали в отдельных вазонах объемом 1 л (по 10 шт. в варианте). Эффективность воздействия амарантина оценивали на 40-е сут после инвазии корней нематодами. Учитывали степень зараженности корня по 5-балльной шкале (1-10 \% - 1 балл; 11-35 \% - 2 балла; 36-70 \% 3 балла; 71-100 \% - 4 балла), наличие сингаллов (число галлов/г корня), массу надземной части и корней, а также морфофизиологические показатели, служащие индикаторами состояния популяции паразита: размеры самок и их плодовитость (число яиц в оотеке) (20).

Содержание хлорофиллов и каротиноидов оценивали по спектрам поглощения этанольных экстрактов листьев (21) на 10-е и 40-е сут после инвазии растений галловой нематодой и некорневой обработки зараженных растений водным раствором амарантина в концентрации 0,5 мг/мл 
(спектрофотометр Solar PВ2201, ЗАО «СОЛАР», Белоруссия).

Для выделения хлоропластов 1 г листьев растирали в среде следующего состава: 0,3 M сахароза; $0,1 \mathrm{M} \mathrm{NaCl}$; 0,01 M $\mathrm{MgCl}_{2} ; 0,05 \mathrm{M}$ трисбуфер; 1 \% бычьего сывороточного альбумина (БСА) (pH 7,5). Профильтрованный через полотно гомогенат осветляли 3 мин при 250 g (центрифуга MPW 251, «MPW Med. Instruments», Польша), осаждая неразрушенные клетки и их крупные фрагменты. Повторное центрифугирование надосадочной жидкости проводили при $1000 \mathrm{~g}$ в течение 10 мин. Осадок хлоропластов суспендировали в среде следующего состава: 0,3 М сахароза; 0,025 M NaCl; 0,01 M MgCl $2 ; 0,05 \mathrm{M}$ трис-буфер (pH 7,5).

Потенциальную способность электрон-транспортной цепи (ЭТЦ) осуществлять перенос электронов воды на феррицианид калия или молекулярный кислород оценивали в условиях раздельного функционирования каждого из этих акцепторов по скорости восстановления $\mathrm{O}_{2}$. Фотовосстановление $\mathrm{O}_{2}$ определяли по его поглощению с реагентом реакции Меллера (адреналином), обладающим способностью взаимодействовать с супероксидным анион-радикалом на восстановительном участке фотосистемы. В реакционную среду вносили адреналин (0,3 мМ) (ФГУП «Московский эндокринный завод», Россия) или феррицианид калия (0,5 мМ). Концентрацию кислорода определяли амперометрически на полярографе Universal polarograf OH-105 («Radelkis», Венгрия) в ячейке объемом 1,2 мл с закрытым платиновым электродом, рН реакционной среды 7,8. Суспензию хлоропластов освещали белым светом (осветитель ЛЭТИ-60, ОАО «Казанский оптико-механический завод», Россия). Концентрацию хлорофилла рассчитывали по формуле Арнона.

Данные обрабатывали с помощью дисперсионного анализа (ANOVA) в программе STATISTICA 6.0 («StatSoft, Inc.», США). В таблицах приведены средние значения $(M)$ и стандартные ошибки средних ( $\pm \mathrm{SEM})$. Достоверность различий оценивали по $t$-критерию Стьюдента. Различия считали статистически значимыми при $\mathrm{p} \leq 0,05$.

Результаты. Обработка семян амарантином в концентрациях 1,0 и 0,5 мг/мл стимулировала прорастание. Семена в опыте проросли на 2-3 сут раньше контрольных. На 5-е и 7-е сут средняя длина корешка у проростков, обработанных амарантином (1,0 мг/мл), превышала показатель в контроле на 10 и $18 \%$ ( $\leq 0,05)$ (табл. 1$)$, в этом варианте также раньше образовывались и развернулись семядольные листья.

1. Всхожесть и развитие корешков у проростков томата (Lycopersicon esculentum Mill.) гетерозисного гибрида $\mathrm{F}_{1}$ Карлсон при обработке семян раствором амарантина в разной концентрации ( $n=20$, in vitro)

\begin{tabular}{|c|c|c|c|c|c|}
\hline \multirow{3}{*}{ Вариант } & \multicolumn{5}{|c|}{ Время после замачивания } \\
\hline & \multirow{2}{*}{$\begin{array}{r}\text { 3-и сут } \\
\text { проросло } \\
\text { семян, \% }\end{array}$} & \multicolumn{2}{|c|}{ 5-e cyт } & \multicolumn{2}{|c|}{ 7-e сут } \\
\hline & & $\begin{array}{l}\text { проросло } \\
\text { семян, \% }\end{array}$ & \begin{tabular}{|l} 
длина корешка, \\
см $(M \pm S E M)$
\end{tabular} & $\begin{array}{l}\text { проросло } \\
\text { семян, \% }\end{array}$ & $\begin{array}{l}\text { длина корешка, } \\
\text { см }(M \pm S E M)\end{array}$ \\
\hline 0,1 мг/мл & 0 & 40 & $0,95 \pm 0,220$ & 100 & $3,34 \pm 0,510$ \\
\hline 0,5 мг/мл & 0 & 50 & $1,22 \pm 0,280$ & 100 & $2,86 \pm 0,090$ \\
\hline 1,0 мг/мл & 40 & 60 & $1,55 \pm 0,430$ & 100 & $3,49 \pm 0,280^{*}$ \\
\hline Контроль (вода) & 0 & 40 & $1,40 \pm 0,470$ & 100 & $2,96 \pm 0,460$ \\
\hline
\end{tabular}

Также было выявлено нематостатическое действие амарантина в концентрациях от 0,5 до 1,0 мг/мл (табл. 2). Личинки в этих растворах теряли подвижность, но восстанавливали ее после выдерживания в дистиллированной воде. В 1,0 мг/мл растворе амарантина утрата подвижности нематод наступала через 24 ч. Выдерживание нематод в 0,5 мг/мл водном растворе в течение 48 ч приводило к потере подвижности $~ 50 \%$ личинок. 
Летальной для личинок была концентрация амарантина 2 мг/мл.

Аналогичные свойства ранее были отмечены у алкалоида физостигмина со схожей с амарантином структурой. Это соединение, выделенное из Calabar bean (сем. Fabaceae), в концентрации 1,0 мг/мл обладало нематостатическим действием на мигрирующую нематоду Ditylenchus dipsaci. Предобработка проростков гороха раствором сульфата физостигмина (0,03 мг/мл) в значительной мере предохраняла растения от заражения нематодой. Возможно, что механизм действия амарантина на нематод аналогичен действию физостигмина (22).

2. Число подвижных личинок галловой нематоды (Meloidogyne incognita) II возраста в растворах амарантина разной концентрации $(M \pm \mathrm{SEM})$

\begin{tabular}{l|c|c|c|c}
\hline \multirow{2}{*}{ Вариант } & \multicolumn{3}{|c|}{ Время после обработки, ч } & \multirow{2}{*}{ В конце эксперимента } \\
\cline { 2 - 3 } & 0 & 24 & 48 & после помещения в воду \\
\hline 0,5 мг/мл & $20 \pm 0,6$ & $20 \pm 0,6$ & $11 \pm 1,8$ & $19 \pm 0,6$ \\
0,75 мг/мл & $20 \pm 1,2$ & $18 \pm 3,0$ & $9 \pm 3,6$ & $17 \pm 3,0$ \\
1,0 мг/мл & 20 & $2 \pm 1,2$ & 0 & $15 \pm 4,1$ \\
2,0 мг/мл & 20 & 0 & 0 & $2 \pm 1,2$ \\
Контроль (вода) & 20 & 20 & $19 \pm 0,6$ & $19 \pm 0,6$ \\
\hline
\end{tabular}

Внекорневая обработка вегетирующих растений водными растворами амарантина в концентрации 0,5 и 1,0 мг/мл приводила к снижению численности паразитирующих на корнях нематод, а также влияла на их морфофизиологические характеристики. На растениях, обработанных растворами амарантина, число половозрелых самок в расчете на 1 г корня на 40-е сут было меньше по сравнению с контролем в 2,1 и 1,3 раза при концентрации соответственно 0,5 и 1,0 мг/мл. Самки нематод из корней обработанных растений оказались в 1,2 раза мельче, а число яиц в их оотеках уменьшалось на 15-20 \% по сравнению с контролем (табл. 3).

3. Рост гетерозисного гибрида томата (Lycopersicon esculentum Mill.) $\mathrm{F}_{1}$ Карлсон при заражении галловой нематодой (Meloidogyne incognita) и развитие нематод на 40-е сут после обработки вегетирующих растений растворами амарантина в разной концентрации $(n=10, M \pm S E M$, вегетационный опыт)

\begin{tabular}{|c|c|c|c|c|c|c|}
\hline \multirow[b]{2}{*}{ Вариант } & \multicolumn{2}{|c|}{ Macca, $\Gamma$} & \multirow[b]{2}{*}{$\begin{array}{l}\text { Балл за- } \\
\text { ражения }\end{array}$} & \multirow[b]{2}{*}{$\begin{array}{l}\text { Число са- } \\
\text { мок/г корня }\end{array}$} & \multirow[b]{2}{*}{$\begin{array}{l}\text { Размер самок (дли- } \\
\text { на×ширина), мм× }{ }^{\circ}\end{array}$} & \multirow{2}{*}{$\begin{array}{l}\text { Число яиц } \\
\text { в оотеке }\end{array}$} \\
\hline & \begin{tabular}{|l|} 
надземных \\
органов
\end{tabular} & корней & & & & \\
\hline Амарантин, 0,5 мг/мл & $32 \pm 1,1^{*}$ & $2,8 \pm 0,40$ & 2 & $324 \pm 39,0^{*}$ & $0,300 \pm 0,0100^{*}$ & $93 \pm 12,0^{*}$ \\
\hline Амарантин, 1,0 мг/мл & $27 \pm 2,4$ & $2,9 \pm 0,60$ & 3 & $544 \pm 54,0$ & $0,298 \pm 0,0070^{*}$ & $90 \pm 17,0^{*}$ \\
\hline $\begin{array}{l}\text { Контроль (зараженные } \\
\text { растения, вода) }\end{array}$ & $24 \pm 1,1$ & $3,1 \pm 0,70$ & 4 & $684 \pm 46,0$ & $0,354 \pm 0,0110$ & $146 \pm 22,0$ \\
\hline $\begin{array}{l}\text { Контроль (здоровые } \\
\text { растения, вода) }\end{array}$ & $29 \pm 2,8$ & $2,4 \pm 0,30$ & - & - & - & - \\
\hline
\end{tabular}

Балл заражения у растений, обработанных амарантином, был существенно ниже, чем у контрольных. Особенно эффективен оказался раствор в концентрации 0,5 мг/мл, при обработке которым число галлов было в 2 раза меньше, чем на корнях контрольных растений. Зараженные растения, обработанные амарантином в концентрации 0,5 и 1,0 мг/мл, превосходили контрольные по массе надземной части соответственно на $32 \%(\mathrm{p} \leq 0,05)$ и $10 \%$. Масса корней у зараженных растений, на которых было обнаружено значительное число галлов и даже сингаллов, оказалась заметно больше, чем у здоровых. Соотношение их массы к массе надземных органов (стебля и листьев) также отличалось от показателя у здоровых растений. При воздействии амарантина соотношение массы корня к массе надземных органов было сопоставимо с показателями у незараженных растений, что свидетельствует о нормализации обменных процессов и фи- 
К числу важных показателей, отражающих физиологический статус растений, относится содержание в хлоропластах фотосинтетических пигментов. В листьях томатов, зараженных нематодой, на 10-е сут количество хлорофиллов увеличилось на $13 \%$, каротиноидов - на $10 \%$ (табл. 4). Возможно, повышение содержания фотосинтетических пигментов было реакцией на окислительный стресс, вызванный внедрением галловой нематоды в корневую систему. Суммарное содержание хлорофиллов и каротиноидов у здоровых и обработанных амарантином растений было практически одинаковым. На 40-е сут наблюдали снижение количества фотосинтетических пигментов в листьях у всех исследуемых растений $(\mathrm{p} \leq 0,05)$. При этом содержание хлорофиллов в зараженных нематодой растениях уменьшилось на $12 \%$, каротиноидов - на $15 \%$, а в обработанных амарантином зараженных растениях эти показатели снизились соответственно на 8 и $5 \%$ по сравнению с незараженными.

4. Содержание хлоропластных пигментов в листьях гетерозисного гибрида томата (Lycopersicon esculentum Mill.) $\mathrm{F}_{1}$ Карлсон при обработке раствором амарантина в зависимости от времени после заражения галловой нематодой (Meloidogyne incognita) ( $n=10, M \pm \mathrm{SEM}$, вегетационный опыт)

\begin{tabular}{l|c|c|c|c|c|c}
\hline \multirow{2}{*}{ Вариант } & \multicolumn{6}{|c}{ Время после заражения } \\
\cline { 2 - 7 } & \multicolumn{2}{|c|}{0 -е сут } & \multicolumn{2}{c}{10 -е сут } & \multicolumn{2}{c}{ 40-е сут } \\
\cline { 2 - 7 } & $\begin{array}{l}\text { хлорофиллы } \\
\mathrm{a}+\mathrm{b}\end{array}$ & $\begin{array}{l}\text { каротино- } \\
\text { иды }\end{array}$ & $\begin{array}{l}\text { хлорофиллы } \\
\mathrm{a}+\mathrm{b}\end{array}$ & $\begin{array}{l}\text { каротино- } \\
\text { иды }\end{array}$ & $\begin{array}{l}\text { хлорофиллы } \\
\mathrm{a}+\mathrm{b}\end{array}$ & $\begin{array}{l}\text { каротино- } \\
\text { иды }\end{array}$ \\
\hline $\begin{array}{l}\text { Амарантин, 0,5 мг/мл } \\
\text { Контроль (заражен- }\end{array}$ & $2,35 \pm 0,087$ & $0,80 \pm 0,025$ & $2,63 \pm 0,121$ & $0,90 \pm 0,018$ & $2,31 \pm 0,074^{*}$ & $0,77 \pm 0,011^{*}$ \\
$\begin{array}{l}\text { ные растения, вода) } \\
\text { Контроль (здоровые }\end{array}$ & $2,29 \pm 0,030$ & $0,79 \pm 0,042$ & $2,50 \pm 0,089$ & $0,83 \pm 0,045$ & $2,11 \pm 0,144$ & $0,60 \pm 0,035$ \\
растения, вода) & $2,30 \pm 0,139$ & $0,81 \pm 0,035$ & $2,65 \pm 0,145$ & $0,91 \pm 0,057$ & $2,40 \pm 0,108^{*}$ & $0,80 \pm 0,014^{*}$ \\
\multirow{2}{*}{ Различия с зараженным контролем статистически значимы при р $\leq 0,05}$. & & \\
\hline
\end{tabular}

Более низкое содержание хлорофиллов и каротиноидов в хлоропластах при заражении галловой нематодой (биогенный стресс) указывает на изменения в работе фотосинтетической цепи электронного транспорта у С3-растений томата. В фотосинтетических системах, кроме основной цепи переноса электронов от воды к НАДФ или искусственному акцептору (нециклический электронный транспорт), работает цепь псевдоциклического транспорта электронов: $\mathrm{H}_{2} \mathrm{O} \rightarrow$ ФС2 $\rightarrow$ ФС1 $\rightarrow \mathrm{O}_{2} \rightarrow \mathrm{H}_{2} \mathrm{O}$. Псевдоциклический транспорт выступает как альтернативный путь переноса электронов, который приводит к восстановлению молекулярного кислорода и образованию супероксид-аниона и $\mathrm{H}_{2} \mathrm{O}_{2}$ (23). Известно, что усиление переноса электронов на кислород может происходить в условиях снижения количества окисленного НАДФ или ингибирования темновых реакций фотосинтеза, а также при действии неблагоприятных факторов. Например, в листьях при дефиците воды в хлоропластах перераспределяется поток электронов, связанных с восстановлением $\mathrm{CO}_{2}$ и $\mathrm{O}_{2}(24,25)$.

5. Электронный транспорт по нециклическому (реакция Хилла) и псевдоциклическому пути (реакщия Меллера) у гетерозисного гибрида томата (Lycopersicon esculentum Mill.) $F_{1}$ Карлсон на 40-е сут после заражения галловой нематодой (Meloidogyne incognita) при обработке раствором амарантина $(n=3$, $M \pm \mathrm{SEM}$, вегетационный опыт)

\begin{tabular}{|c|c|c|}
\hline Вариант & $\begin{array}{l}\text { Реакция Хилла, мкмоль } \\
\mathrm{O}_{2} \cdot \mathrm{M}^{-1} \text { хлорофилла } \cdot \mathrm{q}^{-1}\end{array}$ & $\begin{array}{l}\text { Реакция Меллера, мкмоль } \\
\mathrm{O}_{2} \cdot \mathrm{M}^{-1} \text { хлорофилла } \cdot \mathrm{u}^{-1}\end{array}$ \\
\hline Амарантин, 0,5 мг/мл & $26 \pm 3,0^{*}$ & $17 \pm 2,0^{*}$ \\
\hline Контроль (зараженные растения, вода) & $13 \pm 2,0^{*}$ & $22 \pm 3,0^{*}$ \\
\hline Контроль (здоровые растения, вода) & $64 \pm 4,0$ & $12 \pm 2,0$ \\
\hline * Различия со здоровым контролем с & ски значимы при $\mathrm{p} \leq 0,05$. & \\
\hline
\end{tabular}


В хлоропластах, выделенных из листьев зараженных растений, резко усиливался (до 67 \% при р $\leq 0,05$ ) перенос электронов к молекулярному кислороду по псевдоциклическому пути и снижался - по нециклическому (до 80 \% по сравнению с незараженными растениями) (табл. 5). Обработка листьев зараженных растений водным раствором амарантина в концентрации 0,5 мг/мл приводила к уменьшению переноса электронов на молекулярный кислород до 36 \% по сравнению со здоровыми растениями, и, соответственно, в хлоропластах усиливался перенос электронов (до $30 \%$ ) по нециклическому пути (реакция Хилла).

Обработка амарантином растений, зараженных галловой нематодой, оказывала ауксиноподобное действие: стимулировала рост надземной массы и корней, влияла на содержание хлорофиллов и каротиноидов, а также на скорость переноса электронов по нециклическому и псевдоциклическому пути. Этот факт указывает на то, что молекула амарантина уникальна по своим функциональным свойствам $(12,26)$.

Заражение растений томата галловой нематодой может ослаблять фотосинтез, в том числе первичные процессы фотосинтеза в тилакоидных мембранах. В хлоропластах при развитии окислительного стресса усиливается фотоокисление, что, возможно, становится причиной переключения потока электронов на участке ФСІ с нециклического на псевдоциклический перенос электронов от воды. С псевдоциклическим транспортом электронов связано образование активных форм кислорода (АФК) - супероксидого радикала и $\mathrm{H}_{2} \mathrm{O}_{2}$, что усиливает окислительный стресс в хлоропластах. Свободнорадикальное окисление приводит к разрушению органических молекул, следствием чего может быть нарушение метаболизма и даже гибель растений (27). В регуляции количества АФК принимает участие природная антиоксидантная система, представленная низко- и высокомолекулярными соединениями. Мы показали, что в зараженных растениях томата комплекс защитных механизмов, индуцированных действием экзогенного амарантина, включает накопление антиоксидантов-каротиноидов, переключение нециклического транспорта электронов от воды на участке ФСІ на псевдоциклический, стимуляцию ростовых процессов. Все это в целом приводит к повышению устойчивости растений томата к галловой нематоде.

Аналогичные данные были получены при изучении действия природного адаптогена - фуростаноловых гликозидов, выделенных из культуры клеток Dioscorea deltoidea Wall, на системе паразит-хозяин M. incognita-томаты. Обработка семян и вегетирующих растений томата фуростаноловыми гликозидами заметно снижала поражаемость паразитическими нематодами (7). Препарат оказывал действие на пигментный фонд фотосинтетического аппарата, активность фермента пероксидазы, стимулировал процессы перекисного окисления липидов. Характер изменений в составе хлоропластных пигментов, отмеченный при обработке растений и амарантином, и фуростаноловыми гликозидами, свидетельствует, что эти соединения поддерживают гомеостаз растительной клетки, стимулируя фитоиммунитет самого растения.

Отметим, что исследования, касающиеся поиска природных соединений с нематицидными свойствами, достаточно обширны. Данные о влиянии веществ, полученных из растительного сырья и относящихся к разным классам соединений, на паразитических нематод и устойчивость к ним растений приведены в обзоре D.J. Chitwood (10). Так, индукцию систем- 
ной устойчивости растений к галловой нематоде отмечали в водных экстрактах из свежих листьев лимонной травы Cymbopogon flexuosus Steud. (28) и при обработке надземной части растений масляным экстрактом из семян Argemone mexicana L. (29). Кресс водяной, а также хрен обыкновенный проявляют антагонистические свойства в отношении M. incognita. Фитопрепараты на их основе имеют высокую нематостатическую активность (подавляют вылупление личинок из яиц и парализуют инвазионные личинки), оказывают стимулирующее и стабилизирующее действие на развитие культурных растений. Предобработка фитопрепаратами, содержащими вещества специализированного обмена с нематицидными свойствами, положительно влияет на ростовые процессы и фотосинтез и негативно - на рост и развитие галловой нематоды.

Таким образом, амарантин обладает адаптогенными свойствами, что проявляется в ослаблении негативных биохимических и функциональных сдвигов при реакциях растений томата на стресс, вызванный инвазией нематодами, и активации синтеза соединений, приводящих к улучшению энергетического обмена и восстановительных процессов. Амарантин в концентрации 1,0 и 0,5 мг/мл, с одной стороны, стимулирует прорастание семян и ростовые процессы у растений томата, образование хлорофиллов и каротиноидов, с другой - ингибирует подвижность личинок нематоды и угнетает их развитие в растениях, что отражается на морфометрических и популяционных показателях нематод. Следовательно, амарантин можно рассматривать в качестве нового биогенного индуктора, который в условиях защищенного грунта активирует общие неспецифические системы стрессорного ответа на инвазию фитопатогенов, чем обеспечивает протективный эффект, и при этом обладает ростостимулирующими свойствами.

1ФГБНУ Федеральный научный центр овощеводства, 143080 Россия, Московская обл., Одинцовский р-н, пос. ВНИИССОК, ул. Селекционная, 14,

e-mail: anirr67@yandex.ru $₫$, anirr@bk.ru, vniissok@mail.ru;

2ФГБНУ Институт проблем экологии и эволюции

им. А.Н. Севериова РАН,

119071 Россия, г. Москва, Ленинский просп., 33,

e-mail: udalova.zh@rambler.ru, zinovievas@mail.ru;

зФГБНУ Всероссийский НИИ фундаментальной

и прикладной паразитологии животных и растений

им. К.И. Скрябина - филиал ФГБНУ ФНЦ ВИЭВ РАН,

117218 Россия, г. Москва, ул. Б. Черемушкинская, 28
Поступила в редакцию 29 марта 2019 года

Sel'skokhozyaistvennaya biologiya [Agricultural Biology], 2020, V. 55, № 1, pp. 97-106

\title{
THE EFFECT OF AMARANTHINE ON THE STRESS-RESISTANCE OF TOMATOES (Lycopersicon esculentum Mill.) INVADED BY THE ROOT- KNOT NEMATODE (Meloidogyne incognita)
}

\author{
M.S. Gins ${ }^{1}$, V.K. Gins ${ }^{1}$, P.F. Kononkov' ${ }^{1}$, Zh.V. Udalova ${ }^{2}, 3$, S.V. Zinov'eva ${ }^{2}$
}

\footnotetext{
${ }^{1}$ Federal Research Center for Vegetable Growing, 14, ul. Selektsionnaya, pos. VNIISSOK, Odintsovskii Region, Moscow Province, 143080 Russia, e-mail anirr67@yandex.ru ( $₫$ corresponding author), anirr@bk.ru, vniissok@mail.ru;

${ }^{2}$ Severtsov Institute of Ecology and Evolution, 33, Leninskii prosp., Moscow, 119071 Russia, e-mail udalova.zh@rambler.ru, zinovievas@mail.ru;

${ }^{3}$ Skryabin All-Russian Research Institute of Fundamental and Applied Parasitology of Animals and Plants - Branch of Federal Science Center Kovalenko All-Russian Research Institute of Experimental Veterinary RAS, 28, Bolshaya Cheremushkinskaya ul., Moscow, 117218, Russia ORCID:

Gins M.S. orcid.org/0000-0001-5995-2696

Gins V.K. orcid.org/0000-0002-7053-4345
} 


\begin{abstract}
Root-knot nematodes of the genus Meloidogyne are sedentary parasites that infect the root system of plants, the annual damage from which in the world exceeds 80 billion EUR per year. Infection of plants with these nematodes causes biogenic stress, which is associated with changes in the respiratory processes of plants, a decrease in photosynthesis, the appearance of highly reactive oxygen radicals in the tissues with the formation of toxic intermediate products that cause oxidative stress. The high biological activity of amaranthine isolated from Amarathus tricolor L. combined with antioxidant properties, show the promise of its study as a factor resistance to stress of plant during invasion by parasitic nematodes. In this work, we first showed the adaptogenic properties of amaranthine towards tomato plants infected with root-knot nematode. We investigated the effect of the amaranthine beta-cyanine pigment extracted from $A$. tricolor on the parasite-host system of the tomato $L y$ copersicon esculentum Mill. and root-knot nematode Meloidogyne incognita (Kofoid \& White, 1919) Chitwood 1949. Aqueous solutions of the amaranthine in concentrations from 0.1 to $2.0 \mathrm{mg} / \mathrm{ml}$ were tested. When studying the effect of amaranthine on nematodes in vitro, it was found that the analyzed compound has a nematostatic effect in the range of concentrations from $1.0 \mathrm{mg} / \mathrm{ml}$ and lower. The $2.0 \mathrm{mg} / \mathrm{ml}$ concentration was lethal for $M$. incognita. The effect of amaranthine on biometric and photosynthetic characteristics of tomato plants infected with the root-knot nematode $M$. incogni$t a$, and morphological and physiological parameters of nematodes from plants treated with amaranthine were evaluated in a lab greenhouse. Before planting, the seeds were soaked in amaranthine solutions $(0.5$ and $1.0 \mathrm{mg} / \mathrm{ml})$ for 3 hours, and then seedlings reached the phase of $3-4$ true leaves were sprayed with solutions at the same concentrations and infected with nematodes (three thousand larvae per plant). This experiment revealed stimulating effect of the amaranthine in the tested concentrations on plant development. The treated seeds sprouted 2-3 days earlier than the control seeds, the average root length of the seedlings treated with the $1.0 \mathrm{mg} / \mathrm{ml}$ preparation on day 7 significantly differed from the control $(18 \%, \mathrm{p} \leq 0.05)$. The effect of amaranthine on nematodes was evaluated on day 40 after invasion. A comparative analysis of nematodes from the test and control plants showed that the plant treatment with 0.5 and $1.0 \mathrm{mg} / \mathrm{ml}$ aqueous amaranthine solutions led to a decrease in the number of nematodes on the roots. The number of sexually mature females per gram of roots under the treatment with 0.5 and $1.0 \mathrm{mg} / \mathrm{ml}$ solutions was 2.1 and 1.3 times less compared to the control. Female nematodes from such plants were 1.2 times smaller in both variants; the number of eggs was also $15-20 \%$ less $(p \leq 00.05)$ as compared to control. The complex of protective mechanisms in infected tomato plants induced by the action of exogenous amaranthine includes stabilization of photosynthetic processes disturbed by the nematode, accumulation of carotenoid antioxidants, switching of non-cyclic electron transport from water in the Photosystem I to pseudocyclic, stimulation of tomato plant growth. Out findings indicate that amaranthine exhibits adaptogenic properties associated with the weakening of negative biochemical and functional changes in plants during nematode invasion. Amaranthine can be proposed as a novel biogenic inducer which provides protective effect due to activation of non-specific plant response to biotic stress under pathogen invasion in greenhouse conditions, and also possesses growth-promoting properties.
\end{abstract}

Keywords: amaranthine, antioxidant, adaptogen, Amaranthus tricolor L., variety Valentine, Meloidogyne incognita, tomatoes, chlorophyll, carotenoids, oxidative stress, electron transport.

\title{
REFEREN CES
}

1. Tarchevskii I.A. Katabolizm i stress u rastenii [Plant catabolism and stress]. Moscow, 1993 (in Russ.).

2. Zinovieva S.V. Parazitologiia, 2014, 48(2): 110-130 (in Russ.).

3. Blok V.C., Jones J.T., Phillips M.S., Trudgill D.L. Parasitism genes and host range disparities in biotrophic nematodes: the conundrum of polyphagy versus specialization. BioEssays, 2008, 30(3): 249-259 (doi: 10.1002/bies.20717).

4. Zinov'eva S.V., Vasyukova N.I., Ozeretskovskaya O.L. Prikladnaya biokhimiya i mikrobiologiya, 2004, 40(2): 133-143 (in Russ.).

5. Lavrova V.V., Matveeva E.M., Zinov'eva S.V. Doklady Akademii nauk, 2017, 476(5): 592-595 (doi: 10.7868/S0869565217290254) (in Russ.).

6. Molinari S. Bioassays on plant-nematode interactions. In: Plant bioassays. S.S. Narwal (ed.). Studium Press, LLC, Texas, 2009.

7. Vasil'eva I.S., Udalova Zh.V., Zinov'eva S.V., Paseshnichenko V.A. Steroid furostanol glycosides: a new class of natural adaptogenes (review). Applied Biochemistry and Microbiology, 2009, 
45(5): 463-472 (doi: 10.1134/S0003683809050019).

8. Zinov'eva S.V., Udalova Zh.V., Vasil'eva I.S., Vanyushkin S.A., Paseshnichenko V.A. Prikladnaya biokhimiya i mikrobiologiya, 2001, 37(5): 533-541 (in Russ.).

9. Udalova Zh.V., Zinov'eva S.V. Netraditsionnye sel'skokhozyaistvennye, lekarstvennye i dekorativnye rasteniya, 2006, 1(3): 44-46 (in Russ.).

10. Chitwood D.J. Phytochemical based strategies for nematode control. Annual Review of Phytopathology, 2002, 40: 221-249 (doi: 10.1146/annurev.phyto.40.032602.130045).

11. Gins M.S., Gins V.K., Motyleva S.M., Kulikov I.M., Medvedev S.M., Pivovarov V.F., Mertvishcheva M.E. Metabolites with antioxidant and protective functions from leaves of vegetable amarant (Amaranthus tricolor L.). Sel'skokhozyaistvennaya biologiya [Agricultural Biology], 2017, 52(5): 1030-1040 (doi: 10.15389/agrobiology.2017.5.1030eng).

12. Gins M.S., Kononkov P.F., Gins V.K., Lysenko G.G., Desalen' T.L., Bravova G.B. Physicochemical properties and biological activity of amaranthine in Amarantus caudatus L. plants. Applied Biochemistry and Microbiology, 1998, 34(4): 409-413.

13. Solntsev M.K., Frantsev V.V., Karavaev V.A., Polyakova I.B., Shkol'nikov D.Yu., Burenina A.A., Gins M.S., Gins V.K. Lyuminestsentnye pokazateli list'ev ogurtsa, porazhennykh tripsom i obrabotannykh amarantinom. Collection of Scientific Papers, Faculty of Agriculture in Ceske Budejovice. Series for Crop Sciences, 2004, 21(2): 209-212.

14. Steyn W.P., Daneel M.S., Slabbert M.M. Evaluation of Amaranthus species for their host suitability to the root-knot nematodes, Meloidogyne incognita race 2 and Meloidogyne javanica in South Africa. Acta Hortic., 2013, 1007: 403-407 (doi: 10.17660/ActaHortic.2013.1007.45).

15. Kimaru S.L., Kimenju J.W., Onyango C.M., Kilalo D. Effect of root knot nematodes on the growth of indigenous leafy vegetables in Kenya. African Crop Science Conference Proceedings, 2013, 11: 293-296.

16. Bafokuzara N.D. Influence of six vegetable cultivars on reproduction of Meloidogyne javanica. Journal of Nematology, 1983, 15(4): 559-564.

17. Gins M.S., Gins V.K., Kononkov P.F., Lyubitskii O.B., Vasil'eva O.V. Vestnik rossiiskoi sel'skokhozyaistvennoi nauki, 2005, 4: 50-53 (in Russ.).

18. Ptushenko V.V., Gins M.S., Gins V.K., Tikhonov A.N. Interaction of amaranthin with the electron transport chain of chloroplasts. Russian Journal of Plant Physiology, 2002, 49(5): 585591 (doi: 10.1023/A:1020220430690).

19. Hussey R.S., Barker K.R. A comparison of methods of collecting inocula of Meloidogyne spp., including a new technique. Plant Disease Reporter, 1973, 57: 1025-1028.

20. Zinov'eva S.V., Udalova Zh.V. V sbornike: Morfo-fiziologicheskie adaptatsii paraziticheskikh nematod $k$ rasteniyam [In: Morpho-physiological adaptations of parasitic nematodes to plants]. Moscow, 1994: 9-15 (in Russ.).

21. Lichtenthaler H.K. Chlorophylls and carotenoids: pigments of photosynthetic biomembranes. Methods in Enzymology, 1987, 148: 350-382 (doi: 10.1016/0076-6879(87)48036-1).

22. Bijloo J.D. The "pisum" test: A simple method for the screening of substances on their therapeutic nematicidal activity. Nematologica, 1965, 11(4): 643-644 (doi: 10.1163/187529265X00816).

23. Asada K. The water-water cycle as alternative photon and electron sink. Phil. Trans. R. Soc. Lond. B., 2000, 355(1402): 1419-1431 (doi: 10.1098/rstb.2000.0703).

24. Kuvykin I.V., Vershubskii A.V., Ptushenko V.V., Tikhonov A.N. Oxygen as an alternative electron acceptor in the photosynthetic electron transport chain of C3 plants. Biochemistry Moscow, 2008, 73: 1063-1075 (doi: 10.1134/S0006297908100027).

25. Golding A.J., Johnson G.N. Down-regulation of linear and activation of cyclic electron transport during drought. Planta, 2003, 218: 107-114 (doi: 10.1007/s00425-003-1077-5).

26. Gandía-Herrero F., Gandía-Carmona F. Biosynthesis of betalains: yellow and violet plant pigments. Trends in Plant Science, 2013, 18(6): 334-343 (doi: 10.1016/j.tplants.2013.01.003).

27. Lutskii M.A., Kuksova T.V., Smelyanets M.A., Lushnikova Yu.P. Uspekhi sovremennogo estestvoznaniya, 2014, 12(1): 24-28 (in Russ.).

28. Tiyagi S.A., Ahmad A., Alam M.M. Control of root-knot, reniform and stunt nematodes by root dip in leaf extract of lemongrass. International Pest Control, 1990, 32(3): 70-71

29. Das S., Sukul N.C. Nematicidal effect of the oil from the seeds of Argemone mexicana. Environment and Ecology, 1988, 6(1): 194-197. 